\title{
Heavy Metal Content Screening in Leaves and Flowers of Hypericum montbretii Spach. by Atomic Absorption Spectrometry
}

\author{
İsmühan Potoğlu Erkara*1, Asiye Berber², Okan Sezer ${ }^{3}$ \\ ${ }^{1}$ Eskisehir Osmangazi University, Faculty of Science and Letters, Department of Biology, 26040 Eskisehir, \\ Turkey.orcid.org/0000-0001-5780-4999 \\ 2 Eskisehir Osmangazi University, Faculty of Science and Letters, Department of Elementary Science Education, \\ 26040 Eskisehir, Turkey. orcid.org/0000-0002-8340-4793 \\ ${ }^{3}$ Eskisehir Osmangazi University, Faculty of Science and Letters, Department of Biology, 26040 Eskisehir, \\ Turkey. orcid.org/0000-0001-7304-1346 \\ ${ }^{*}$ Corresponding author: ismuhan@ogu.edu.tr \\ Received: 18 February 2021, Accept: 15 March 2021, Published Online: 01 June 2021
}

\begin{abstract}
Atomic absorption spectrometry facilitates the reliable determination of mineral content during pharmaceutical quality control of medicinal plants. In the present work, measurable amounts of $\mathrm{Fe}, \mathrm{Ca}, \mathrm{Cu}, \mathrm{K}, \mathrm{Mg}, \mathrm{Mn}, \mathrm{Na}$ and $\mathrm{Zn}$ were detected in the leaves and flowers of Hypericum montbretii Spach. through atomic absorption spectrometry. Mean heavy metal content in the flowers and leaves of $H$. montbretii Spach. was, in descending order, $\mathrm{Ca}>\mathrm{Mg}>$ $\mathrm{K}>\mathrm{Mn}>\mathrm{Na}$. Ca was present in higher concentrations in the leaves (10252.75 ppm) and flowers (7321.94 ppm) of titled plant. Our results reveal that flowers are less suitable as target plant parts for metal accumulation than leaves.
\end{abstract}

Key words: Hypericum montbretii Spach., heavy metals, atomic absorption spectrometry.

\section{Introduction}

The environment in developing countries, pollution in irrigation water, atmosphere, soil, sterilization methods and storage conditions all play an important role in the contamination of medicinal plants by metals. Metals may contaminate a variety of plants causing onsuing serious health hazards such as kidney damage, renal failure and liver damage (Shaw et al., 1997; Andrew et al., 2003; Ajasa et al., 2004). Iron, zinc, calcium, magnesium, copper, potassium, manganese, sodium were chosen as representative metals whose levels in the environment represent a reliable index of environmental pollution and human health. Some plants like as Hypericum perforatum, Avena sterilis, Bifora radians, Chenopodium album, Consolida regalis, Humulus lupulus, Reseda lutea, Solanum nigrum, Sorghum halepense and Xanthium strumarium can then be used as biomonitors for the determination of trace element levels (Gomez et al., 2004; Kadıoğlu et al., 2005; Gomez et al., 2007; Özcan and Akbulut, 2007). 
Hypericum L., which is a member of the Hypericaceae (Guttiferae) family, is represented approximately 500 species all around to world. About 108 of these species are naturally distributed in Turkey (Robson, 1967; Robson, 1977; Robson, 2012; Duman and Çakır-Dindar, 2020). There has been many studies previously conducted on the Hypericum species, but very limited studies for $\mathrm{H}$. origanifolium. According to the literature reviews, only one anatomical study on $\mathrm{H}$. montbretii was found (Potoğlu Erkara and Tokur, 2004). One of the most important features of Hypericum taxa is their unique secondary metabolites. Hypericum taxa and their metabolites are widely used in traditional and modern medicine today (Yaylacı et al., 2013). In the light of phytochemical studies performed on $\mathrm{H}$. montbretii, flavonoids (myrcetin, rutin, quercetin, hyperoside), xanthones (iso-magniferin and mangiferin), naphthodiantrones (frangulin, emodin, proto-pseudohypericin, psudohypericin and phenolicin) and phenolic acids have been determined at the aerial parts of the plant (Mathis and Ourisson, 1964; Kitanov and Nedialkov, 1998; Makovests'ka, 1999; Sirvent et al., 2002; Çırak et al., 2007; Öztürk et al., 2009; Bertoli et al., 2015).

Data available on the biological activity of $H$. montbretii is also limited to a few previous reports that have demonstrated their cytotoxic, antiproliferative, antimicrobial, antibacterial, antiyeast and antioxidant activities (Sakar et al., 1988; Sakar and Tamer, 1990; Güzey, 2007; Çırak et al., 2007; Öztürk et al., 2009; Güzey et al., 2011; Yaşar et al., 2013; Bertoli et al., 2015; Boran, 2018). In the light of literature data, any studies on the heavy metal content of $H$. montbretii not determined.

The main purpose of this study is to determine the heavy metal content in extracts obtained from the flowers and leaves of $H$. montbretii by atomic absorption spectrometry. We hope that the relationship between the heavy metal amounts in $\mathrm{H}$. montbretii leaves and flowers will be reference for future studies.

\section{Material and Methods}

H. montbretii Spach. was collected around of Eskişehir, Turkey. H. montbretii Eskişehir: Kalabak village and its surrounding area, 1300 m. under the forest, June 2003 (OUFE: 10332). Eskişehir: Kirazlı village, Springs, $1500 \mathrm{~m}$., alongside the road, June 2003 (OUFE: 10333). The plant was identified according to Flora of Turkey and the East Aegan Islands (Robson, 1967, 1988; Dönmez, 2000).

For the solid samples with a nitric acid (Merck, Darmstadt, Germany) - perchloric acid (Merck, Darmstadt, Germany) digestion was used for mineralizing. The dried flowers and leaves of $H$. montbretii were extracted for the solution phase as described previously (Que Hee and Boyle, 1988). and analyzed for Fe, $\mathrm{Zn}, \mathrm{Ca}, \mathrm{Mg}, \mathrm{Cu}, \mathrm{K}, \mathrm{Mn}$, $\mathrm{Na}$ (Merck AAS standard solutions), using Hitachi (180-70) Polorized Zeeman flame atomic absorption spectrometry. All precautions were taken to prevent metal contamination, i.e. samples were cleaned with $2 \% \mathrm{HNO}$, rinsed in distilled water and baked at $600{ }^{\circ} \mathrm{C}$. All samples were analyzed in triplicate and the mean values were calculated. In order to increase the reliability of the measurements during the study, the instrument was calibrated at every 10 readings.

The flame atomic absorption spectrometry (FAAS) instrumental and operating conditions that provided the best sensitivity for the determination of metal content are detailed in Table 1. 
Table 1. FAAS instrumental parameters employed to determine metals.

\begin{tabular}{|c|c|c|c|c|c|c|}
\hline Elements & $\begin{array}{c}\text { Flame } \\
\text { type }\end{array}$ & $\begin{array}{c}\text { Burner height } \\
(\mathrm{mm})\end{array}$ & $\begin{array}{c}\text { Wavelength } \\
(\mathrm{nm})\end{array}$ & $\begin{array}{c}\text { Slit width } \\
(\mathrm{nm})\end{array}$ & $\begin{array}{c}\text { Lamp Current } \\
(\mathrm{mA})\end{array}$ & $\begin{array}{c}\text { Fuel } \\
\text { gas } \\
\left(1 \mathrm{~min}^{-1}\right)\end{array}$ \\
\hline $\mathrm{Fe}$ & Air- $\mathrm{C}_{2} \mathrm{H}_{2}$ & 7.5 & 248.3 & 0.2 & 10 & 2.3 \\
\hline $\mathrm{Zn}$ & Air- $\mathrm{C}_{2} \mathrm{H}_{2}$ & 7.5 & 213.8 & 1.3 & 10 & 2.0 \\
\hline $\mathrm{Ca}$ & Air- $\mathrm{C}_{2} \mathrm{H}_{2}$ & 12.5 & 422.7 & 2.6 & 7.5 & 2.6 \\
\hline $\mathrm{Mg}$ & Air- $\mathrm{C}_{2} \mathrm{H}_{2}$ & 7.5 & 285.2 & 2.6 & 7.5 & 1.6 \\
\hline $\mathrm{Cu}$ & Air- $\mathrm{C}_{2} \mathrm{H}_{2}$ & 7.5 & 324.8 & 1.3 & 7.5 & 2.3 \\
\hline $\mathrm{K}$ & Air- $\mathrm{C}_{2} \mathrm{H}_{2}$ & 7.5 & 766.5 & 2.6 & 10 & 2.3 \\
\hline $\mathrm{Mn}$ & Air- $\mathrm{C}_{2} \mathrm{H}_{2}$ & 7.5 & 279.5 & 0.4 & 7.5 & 2.3 \\
\hline $\mathrm{Na}$ & Air- $\mathrm{C}_{2} \mathrm{H}_{2}$ & 7.5 & 589.0 & 0.4 & 10 & 2.2 \\
\hline
\end{tabular}

\section{Results and Discussion}

In this study, the heavy metal contents of the leaves and flowers of Hypericum montbretii Spach. were investigated. These levels were obtained through flame atomic absorption spectrometry. $\mathrm{Fe}, \mathrm{Zn}, \mathrm{Ca}, \mathrm{Mg}, \mathrm{Cu}, \mathrm{K}$, $\mathrm{Mn}$ and $\mathrm{Na}$ were determined to be present in the samples. Metal concentrations in the leaves of $H$. montbretii were found to be 68.096, 38.991, 10252.750, 6463.236, 5.570, 2019.217, 166.759 and $86.687 \mathrm{ppm}$; and in flower of $H$. montbretii were found to be $150.617,41.564,7321.943,9503.734,13.312,4694.398,105.095$ and $93.040 \mathrm{ppm}$ for iron, zinc, calcium, magnesium, copper, potassium, manganese, sodium, respectively (Table 2, Figure 1).

$\mathrm{Fe}, \mathrm{Zn}, \mathrm{Mg}, \mathrm{Cu}, \mathrm{K}$ and $\mathrm{Na}$ concentrations were recorded as higher in the flower than in the leaf, 150.617> 68.096 ppm, 41.564> 38.991 ppm, 9503.734> 6463.236 ppm, 13.312> 5.570 ppm. 4694.398> 2019.217 ppm, 93.040> $86.687 \mathrm{ppm}$, respectively. Ca and Mn concentrations were observed to be higher in the leaf than in the flower 10252.750> 7321.943 ppm, 166.759> 105.095 ppm, respectively (Figure 1, Table 2).

Table 2. Element concentrations of $H$. montbretii (ppm).

\begin{tabular}{|c|c|c|}
\hline \multirow{2}{*}{ Elements } & \multicolumn{2}{|c|}{ H. montbretii } \\
\cline { 2 - 3 } & leaf & flower \\
\hline $\mathrm{Fe}$ & 68.096 & 150.617 \\
\hline $\mathrm{Zn}$ & 38.991 & 41.564 \\
\hline $\mathrm{Ca}$ & 10252.750 & 7321.943 \\
\hline $\mathrm{Mg}$ & 6463.236 & 9503.734 \\
\hline $\mathrm{Cu}$ & 5.570 & 13.312 \\
\hline $\mathrm{K}$ & 2019.217 & 4694.398 \\
\hline $\mathrm{Mn}$ & 166.759 & 105.095 \\
\hline $\mathrm{Na}$ & 86.687 & 93.040 \\
\hline
\end{tabular}




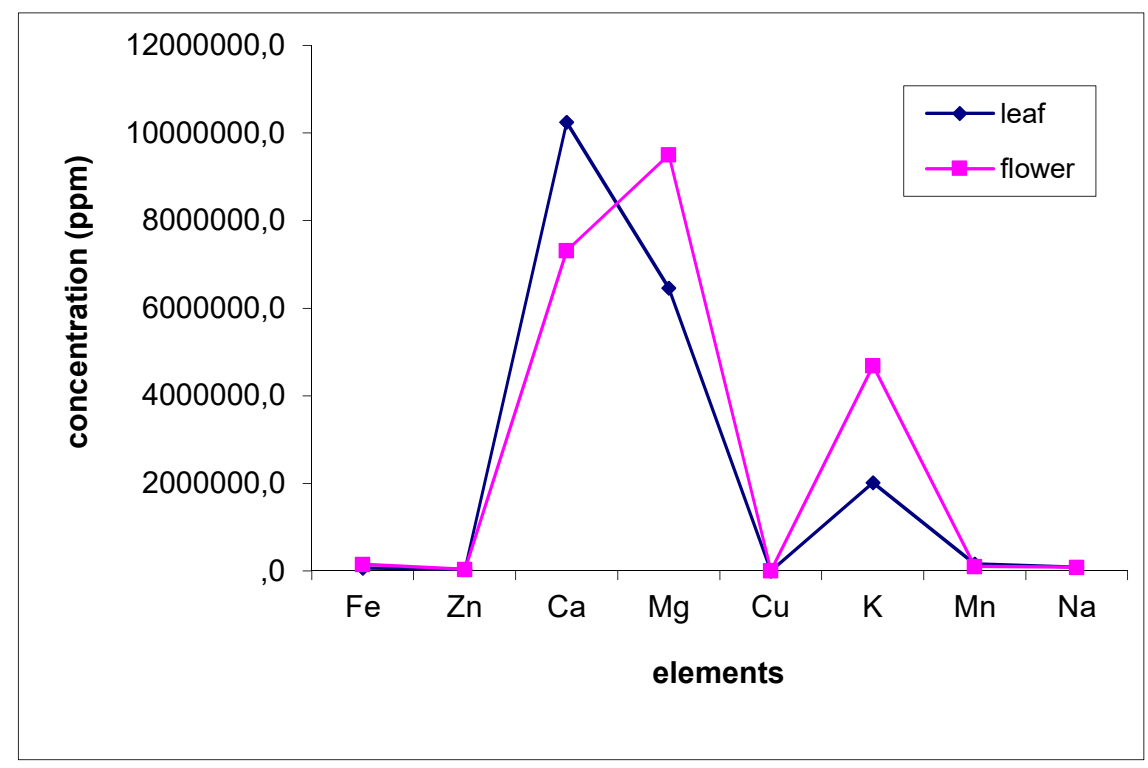

Figure 1. Relationship between leaf and flower metal concentrations of $H$. montbretii.

The mean heavy metal content in the flowers and leaves of $H$. montbretii was, in descending order, $\mathrm{Ca}>$ $\mathrm{Mg}>\mathrm{K}>\mathrm{Mn}>\mathrm{Na}$. Ca was present in higher concentrations in the leaves (10252.750 ppm) and flowers $(7321.943$ ppm) of the titled plant. Gomez et al. indicated that the Ca concentration in Hypericum perforatum was 100-500 ppm for the dried herb, as indicated in table (Gomez et al., 2004). This situation shows that the Ca concentration of the leaf and flower of $H$. montbretii is higher than Hypericum perforatum. Kadıoglu et al. (2005) found the concentrations to be 495, 62.6, 11.1, 19,5 ppm for iron, manganese, copper, zinc, respectively (Özcan and Akbulut, 2007). In this study, the concentrations of $\mathrm{Mn}$ and $\mathrm{Zn}$ were higher, while that of Fe was lower than in the Hypericum perforatum concentrations reported by Kadıoğlu et al. (2005).

Elemental studies of the plants revealed that they contained large amounts of nutrients and were rich in $\mathrm{Mg}, \mathrm{Ca}, \mathrm{Na}$ and $\mathrm{K}$ (Ajasa et al., 2004). The results above indicated that the herbal plants contain large amounts of nutrients and are rich in $\mathrm{Mg}, \mathrm{Ca}$ and $\mathrm{K}$. The abundance of $\mathrm{K}, \mathrm{Mg}$ and $\mathrm{Ca}$, demonstrated as a result of this analysis, was in agreement with previous findings that these three metals represent the most abundant metal constituents of many plants. Variations in the metal concentration of plants from different sites are related to their condition. These differences might be due to growth conditions, genetic factors, geographical variations and analytical procedures in the locale from which the samples are collected. Though much is known about the functional role of a number of elements, the best foreseeable benefit for human health, mineral nutrition, lies in obtaining the correct amount of supplementation in the right form at the right time. Deficiency or excess of $\mathrm{Cu}, \mathrm{Mn}, \mathrm{Zn}, \mathrm{Ca}, \mathrm{Mg}$ and $\mathrm{K}$ may cause a number of disorders (Ajasa et al., 2004). These elements also play a part in neurochemical transmission, as well as serving as constituents of biological molecules, as a cofactor for various enzymes, and in a variety of different metabolic processes.

High amounts of $\mathrm{Ca}$ are expected one way or another, as it is one of the most common minerals of the soil, from where it is readily absorbed into the plants. Iron is an important element for the human body and plays a role in oxygen and electron transfer, as well as being essential for the formation of haemoglobin. Copper and Zinc 
are required in our diet because they exhibit a wide range of biological functions, such as being components of the enzymatic and redox systems (Özcan and Akbulut, 2007). The results also show that many of these plants contain elements of vital importance to man's metabolism, and that they are also needed for growth and development, as well as in the prevention and healing of diseases.

While many investigations into the quality values of medicinal plants are being reported in the current literature (Gomez et al., 2007), less emphasis has been made on the metal content of herbal products. Metallic elements are constituent plant compounds demonstrating biological activity as essential or toxic agents in metabolism. Thus, the application of metal monitoring as a pattern recognition method in medicinal herbs is a promising tool for their characterization.

\section{Conclusion}

The classification of biological species in relation to their chemical composition, which of course includes metal species, is also important in the area of chemotaxonomy. Heavy metal levels are important pollutants for soil, water, plant, the environment and human health. Some species can be used as biomonitors in the determination of trace heavy metal levels. Therefore, further investigations are also needed to determine interactions between the leaves and flowers in terms of heavy metals.

\section{Conflicts of Interests}

Authors declare that there is no conflict of interests

\section{References}

Ajasa, A. M. O., Bello, M. O., Ibrahim, A. O., Ogunwande, I. A., \& Olawore, N. O. (2004). Heavy trace metals and macronutrients status in herbal plants of Nigeria. Food Chemistry, 85, 67-71.

Andrew, A. S., Warren, A. J., Barchowsky, A., Temple, K. A., Klei, L., Soucy, N. V., O'Hara, K. A., \& Hamilton, J. W. (2003). Genomic and Proteomic Profiling of Responses to Toxic Metals in Human Lung Cells. Environ. Health Perspect, 111(6), 825-835.

Bertoli, A., Çırak, C., \& Seyis, F. (2015). Hypericum origanifolium Willd.: The essential oil composition of a new valuable species. Industrial Crops and Products, 77, 676-679.

Boran, R. (2018). Investigations of anti-aging potential of Hypericum origanifolium Willd. for skincare formulations. Industrial Crops and Products, 118, 290-295.

Çırak, C., Radušienè, J., Ivanauskas, L., \& Janulis, V. (2007). Variation of bioactive secondary metabolites in Hypericum origanifolium during its phenological cycle. Acta Physiologiae Plantarum, 29(3), 197-203.

Dönmez, A. A. (2000). Hypericum L. - In: Flora of Turkey and the East Aegean Islands (Vol.11), (Güner, A, Özhatay N, Ekim, T., \& Başer, K. H. C) (Eds.) Edinburgh: Edinburgh University Press, pp. 71-72.

Duman, H., \& Çakır-Dindar, E. G. (2020). Hypericum alacamdaglariense (Hypericaceae), a new species from Turkey. Phytotaxa, 470(2), 176-185. 
Gomez, M. R., Cerutti, S., Olsina, R. A., Silva, M. F., \& Martinez, L. D. (2004). Metal content monitoring in Hypericum perforatum pharmaceutical derivatives by atomic absorption and emission spectrometry. Journal of Pharmaceutical and Biomedical Analysis, 34(3), 569-576.

Gomez, M. R., Cerutti, S., Sombra, L. L., Silva, M. F., \& Martinez, L. D. (2007). Determination of heavy metals for the quality control in argentinian herbal medicines by ETAAS and ICP-OES. Food and Chemical Toxicology, 45, 1060-1064.

Güzey. G. (2007). Cytotoxic and Antiproliferative Effects of Hypericum perforatum, Hypericum montbretti and Hypericum origanifolium Species on A549, HeLa and NIH3T3 Cell Cultures. PhD. Thesis, Anadolu University Institute of Health Sciences, Eskişehir, Turkey.

Güzey, G., Ibadova, S., Öztürk, Y., Öztürk, N., Maggi, F., Sagratini, G., Ricciutelli, M., \& Vittori, S. (2011). Antiproliferative and Antioxidant Effects of Three Hypericum Species of Turkish Origin: $\mathrm{H}$. perforatum, $\mathrm{H}$. montbretii and H. origanifolium. Medicinal and Aromatic Plant Science and Biotechnology, 5(1), 91-99.

Kadıoğlu, I., Mendil, D., Sarı, H., \& Hasdemir, E. (2005). Determination of Heavy Metal Levels in Some Weeds Collected from Tokat, Turkey. Asian Journal of Chemistry, 17(1), 564-568.

Kitanov, G. M., \& Nedialkov, P. T. (1998). Mangiferin and isomangiferin in some Hypericum species. Biochemical Systematics and Ecology, 26, 647-653.

Makovests'ka, O. Y. (1999). Research of biologically active substances of Hypericum L. species. Report Vl. Sections olympia (Spach) Nyman, oampylopus Boiss. and origanifolia Stef. Farmatsevtichnii Zhurnal (Kiev), 6 , 46-50.

Mathis, C., \& Ourisson, G. (1964). Chemo-taxonomic study of the genus Hypericum. III. The distribution of saturated hydrocarbons and monoterpenes from the essential oil of Hypericum. Phytochemistry, 3, 133-141.

Özcan, M. M., \& Akbulut, M. (2007). Estimation of minerals, nitrate and nitrite contents of medicinal and aromatic plants used as spices, condiments and herbal tea. Food Chemistry, 106, 852-858.

Öztürk, N., Tunçel, M., \& Potoğlu Erkara, İ. (2009). Phenolic compounds and antioxidant activities of some Hypericum species: A comparative study with H. perforatum. Pharmaceutical Biology, 47(2), 120-127.

Que Hee, S. S., \& Boyle, Jr. (1988). Simultaneous multielemental analysis of some environmental and biological samples by inductively coupled plasma atomic emission-spectrometry. Analytical Chemistry, 60(10), 10331042.

Potoğlu Erkara, I., \& Tokur, S. (2004). Morphological and anatomical investigations on some Hypericum L., species growing naturally in and arround Eskişehir. Trakya University Journal of Natural Sciences 5, 97-105.

Robson, N. K. B. (1967). Hypericum L. - In: Flora of Turkey and the East Aegean Islands (Vol. 2), (Davis, P. H.) (Ed.) Edinburgh: Edinburgh University Press., p. 355.

Robson, N. K. B. (1977). Studies in the genus Hypericum L. (Guttiferae): 1. Infrageneric classification. Bulletin of the British Museum (Natural History) Botany, 5, 291-355.

Robson, N. K. B. (1988). Hypericum L. - In: Flora of Turkey and the East Aegean Islands (Vol.10), (Davis, P. H., Mill, R. R., \& Tan, K.) (Eds.) Edinburgh: Edinburgh University Press., p. 96. 
Robson, N. K. B. (2012). Studies in the genus Hypericum L. (Hypericaceae) 9. Addenda, corrigenda, keys, lists and general discussion. Phytotaxa, 72, 1-111.

Sakar, M. K., Tamer, A. U., \& Tokur, S. (1988). Antimicrobial activities of some Hypericum species growing in Turkey. Fitoterapia, 59, 49-52.

Sakar, M. K., \& Tamer, A. U. (1990). Antimicrobial activity of different extracts from some Hypericum species. Fitoterapia, 61, 464-466.

Shaw, D., Leon, C., Kolev, S., \& Murray, V. (1997). Traditional remedies and food supplements. A 5-year toxicological study (1991-1995). Drug Safety, 17, 342-356.

Sirvent, T. M., Walker, L., Vance, N., \& Gibson, D. M. (2002). Variation in hypericins from wild populations of Hypericum perforatum L. in the Pacific Northwest of the USA. Economic Botany, 56, 41-48.

Yaşar, Ş. N., Can, Ö. D., Öztürk, N., Sagratini, G., Ricciutelli, M., Vittori, S., \& Maggi, F. (2013). Central nervous system activities of Hypericum origanifolium extract via GABAergic and opioidergic mechanisms. Phytotherapy Research, 27(6), 877-884.

Yaylacı, Ö. K., Özgişi, K., Sezer, O., Orhanoğlu, G., Öztürk, D., \& Koyuncu, O. (2013). Anatomical studies and conservation status of rare endemic Hypericum sechmenii Ocak \& Koyuncu (Sect: Adenosepalum) from Eskişehir-Turkey. Journal of Selcuk University Natural and Applied Science, 2(1), 1-11. 